\title{
"Sem Pressão": application with guidelines for identification, staging and prevention of pressure injuries
}

\section{"Sem Pressão": aplicativo com orientações para identificação, estadiamento e prevenção de lesões por pressão}

\section{"Sem Pressão": aplicación con orientaciones para identificación, classificación y prevención de lesiones por presión}

Rosana Siqueira Campos ${ }^{1, *}$, Leila Blanes ${ }^{1}$, Denise Nicodemo ${ }^{1}$, Lydia Masako Ferreira $^{1}$

\section{ORCID IDs}

Campos RS (D) https://orcid.org/0000-0002-8905-3939

Blanes L (D) https://orcid.org/0000-0002-6922-7719

Nicodemo D (D) http://orcid.org/0000-0002-0510-009X

Ferreira LM (D) https://orcid.org/0000-0003-4587-509X

\section{HOW TO CITE}

Campos RS; Blanes L; Nicodemo D; Ferreira LM. "Sem Pressão": application with guidelines for identification, staging and prevention of pressure injuries. ESTIMA, Braz. J. Enterostomal Ther., 2020, 18: e3120. https://doi.org/10.30886/estima.v18.944_IN

\begin{abstract}
Objective: develop an application with guidance on the identification, staging and prevention of pressure injuries in adults. Method: the descriptive method used started with the search for applications in the area of pressure injuries on the Google $\odot$ and Apple (c) platforms. Afterwards, the content was developed, based mainly on the recommendations of the National Pressure Injury Advisory Panel. A prototype was created at www.fábricadeaplicativos.com.br and sent for evaluation of form and content. Six health professionals completed a questionnaire evaluating the application and two of them suggested changes. The application was adequate to the suggestions and reassessed by three stomatherapist nurses who did not suggest changes. Results: the application was developed on the "application factory" website and named "Sem Pressão" (No Pressure), with seven tabs. Conclusion: the application was created with guidelines on identification, staging and prevention of pressure injuries in adults, and made available for free download.
\end{abstract}

DESCRIPTORS: Pressure injury; Information Technology; Technological development; Smartphone; Wounds and injuries.

\footnotetext{
1. Universidade Federal de São Paulo - Escola Paulista de Medicina - Programa de Pós-Graduação em Ciência, Tecnologia e Gestão Aplicadas à Regeneração Tecidual - São Paulo (SP), Brazil.
}

*Correspondence author: ladynurse@gmail.com

Received: Sep. 24, 2020 | Accepted: Nov. 06, 2020 


\section{RESUMO}

Objetivo: desenvolver aplicativo com orientações sobre identificação, estadiamento e prevenção de lesões por pressão em adultos. Método: o método descritivo utilizado iniciou com a busca de aplicativos na área de lesões por pressão nas plataformas Google@ e Apple@ . Após, foi desenvolvido o conteúdo, baseado, principalmente, nas recomendações da National Pressure Injury Advisory Panel. Foi criado um protótipo em www.fábricadeaplicativos.com.br e enviado para avaliação de forma e conteúdo. Seis profissionais de saúde preencheram um questionário avaliando o aplicativo e dois deles sugeriram alterações. O aplicativo foi adequado às sugestões e reavaliado por três enfermeiros estomaterapeutas que não sugeriram alterações. Resultados: o aplicativo foi desenvolvido no site "fábrica de aplicativos" e denominado "Sem Pressão", com sete abas. Conclusão: foi criado o aplicativo com orientações sobre identificação, estadiamento e prevenção de lesões por pressão em adultos, e disponibilizado para download gratuito.

DESCRITORES: Lesão por pressão; Tecnologia da informação; Desenvolvimento tecnológico; Smartphone; Ferimentos e lesões.

\section{RESUMEN}

Introducción: Lesiones por Presión representan una de las principales complicaciones en pacientes hospitalizados, prolongando la internación y aumentando los costos globales de la asistencia. Recursos para orientación de profesionales, como sitios web y directrices apoyan en la identificación, prevención y classificación. La aplicación para teléfonos inteligentes se presenta como una estrategia educativa para detener estos profesionales y la ausencia de esta tecnología libre y en portugués instigado este trabajo. Objetivo: Desarrollar aplicación con orientaciones sobre identificación, classificación y prevención de Lesiones por Presión en adultos. Método: El método descriptivo utilizado inició con la búsqueda de aplicaciones en el área de Lesiones por Presión en las plataformas Google (c) y Apple ( ). Después, se desarrolló el contenido, baseado principalmente en las recomendaciones del National Pressure Injury Advisory Panel. Se creó un prototipo en www.fábricadeaplicativos.com.br y enviado para evaluación de forma y contenido. Seis profesionales de la salud llenaron un cuestionario evaluando la aplicación y dos de ellos sugirieron cambios. La aplicación fue adecuada a las sugerencias y reevaluado por 3 enfermeros estomaterapeutas, que no sugirieron cambios. Resultado: La aplicación fue desarrollada en el sitio "fabricadeaplicativos.com.br" y se denominó "Sem Pressão", con siete pestañas (http://app.vc/sem_pressao). Conclusión: Se creó la aplicación "Sem Pressão", con orientaciones sobre identificación, classificación y prevención de Lesiones por Presión en adultos y disponible para descarga gratuita.

DESCRIPTORES: Úlcera por Presión; Tecnología de la Información; Desarrollo tecnológico; Teléfono inteligente; Heridas y lesiones.

\section{INTRODUCTION}

Pressure injuries (PI) are defined as injuries located on the skin and/or underlying tissue, usually on bony prominence, resulting from isolated pressure or pressure combined with friction and/or shear. Numerous contributing factors may be associated with PI, but their meaning has yet to be elucidated ${ }^{1,2}$. These lesions can appear as intact or open skin and can be painful. Tolerance of the tissue to pressure can be influenced by microclimate, nutrition, tissue perfusion, comorbidities and the specific conditions of the tissue ${ }^{1}$.

PIs can also be related to the use of medical devices. These are areas located on the underlying skin or tissue as a result of sustained pressure from a device ${ }^{1}$. Soft tissue injuries usually reproduce the shape of the device, which is usually rigid or fixed with tight dressings. These PIs can progress to full thickness lesions due to the lack of adipose tissue in many areas of ulceration ${ }^{3,4}$. Critical patients are susceptible to the development of PI related to devices for several reasons, such as edema, lack of sensitivity and peripheral vasoconstriction ${ }^{3}$.

Risk factors for the development of these injuries are related to mobility, humidity, activity, sensory perception, nutritional pattern, friction and shear1. The most susceptible patients are those who are immobile, both in bed and in a wheelchair, whether elderly or young people with some sensory impairment, such as trauma, coma, extensive surgical procedures, among others ${ }^{5}$.

PI are considered an important health problem for the general population, as they represent one of the main complications that affect hospitalized patients, prolonging hospitalization and increasing the overall costs of care6. They are also considered an indicator of quality of care in health services ${ }^{5,7}$ and classified internationally as adverse events and represent a challenge, as they increase morbidity, mortality, duration and costs of treatment8, in addition to interfering with the quality of life of patients with PI9. 
Chacon and collaborators ${ }^{10}$ identified the costs of treating stages 3 and 4 of PI in hospitalized patients, with the average cost calculated being $\mathrm{R} \$ 8.889,63$. Dealey, Posnett and Walker ${ }^{11}$ identified costs for treating PI in England and ranged from $£ 1,064.00$ for stage 1 to $£$ $10,551.00$ for stage 4 .

The introduction of computer technology and the emergence of sophisticated gadgets, such as computers, notebooks, palmtops, tablets, smartphones and portable phones with internet support, have brought many benefits to health care, allowing professionals access, anywhere, anytime, to a lot of information about the patient or their illness ${ }^{12}$. There are resources to guide health professionals on the topic, such as specific websites, classes, texts, guidelines. Among these features, the smartphone application (app) stands out, which is a type of software that allows the user to perform specific tasks. They exist for computers and for cell phones or smartphones, called mobileapps ${ }^{13}$.

The smartphone is considered an easy-to-use tool that can reach a large portion of nurses and other professionals in the health staff ${ }^{14}$. Smartphones have revolutionized the way people communicate today. They provide wireless information services, including internet browsing, high-resolution touch screens, highspeed data access via $\mathrm{Wi}-\mathrm{Fi}$ and broadband, and highcapacity digital camera ${ }^{14}$.

Mobile communication and information technologies can help implement protocols for ulcer care and the monitoring of high-risk patients, preventing or improving these conditions ${ }^{15}$. The way of interacting today is intensely influenced by information and communication technologies, and it is very important to intensify these types of alternatives in the different scenarios of health education, using them for specific purposes and with beneficial objectives ${ }^{16}$.

Therefore, it is necessary to develop resources such as applications that contain reference files for the correct identification, staging and prevention of PI. Access to knowledge facilitates early diagnosis, reducing the time and cost of treatment. In addition, it provides for the implementation of preventive measures, which are fundamental in reducing PI and its complications, as well as ensuring patient safety.

Thus, the objective of this study was to develop an application that can be used by health professionals, with guidelines for identifying, staging and preventing PI in adults.

\section{METHOD}

Descriptive methodological study of developing a smartphone application for guidance on identifying, staging and preventing PI in adults. The study was approved by the Research Ethics Committee of the Federal University Universidade Federal de São Paulo (UNIFESP), with CAAE 78020117.0.0000.5505, of October 18, 2017.

The work started with the search for precedence in the Google $\odot$ and Apple $\odot$ platforms, researching the existence of applications in the area of prevention and treatment of PI. The keywords used in the search were:Wounds, Pressure Ulcer, Pressure Sore, Pressure Injury, Decubitus Ulcer, Ferida, Úlcera por Pressão, Úlcera de Decúbito, Lesão por Pressão. Only applications that offered scientific knowledge in the area were considered for the research, being excluded those for entertainment. In December/2016, on the Google $\odot$ and Apple $($ platforms, 76 applications were found in the area of wounds and PI. Of these, $84 \%$ were in English and 16\% in other languages, such as French, Italian and Spanish. Only one app was found in Portuguese, but its use is exclusive to the staff of a hospital in the city of São Paulo. As for the cost, 57 of them were free and 19 were paid.

The search for anteriority was also carried out in the PUBMED, Scielo and Lilacs databases and in the Google Scholar search platform. An article was found related to applications in the area of PI, but not aimed at preventing injury, but monitoring it ${ }^{15}$.

Based on this search, the application was developed in five stages: bibliographic survey, content development, programming and design on the creation platform, application evaluation and availability on the download platform.

The content of the application was based on recent articles published on PI in the recommendations of the National Pressure Injury Advisory Panel (NPIAP), of 2014 and 2016, in the Patient Safety Protocol of Agencia Nacional de Vigilância Sanitária (ANVISA),of 2013, and in the book of Prevention and Treatment of Pressure Injury ${ }^{17}$. 
In order to illustrate and assist in the correct identification of injuries, an item was created: Staging Pictures. This item contains images of the author (photographed with prior authorization from patients), obtained during previous clinical practice and also images from NPIAP for authorized use. In addition to the images, the Braden Scale validated for the Portuguese language was used, also with authorized use. This scale is an instrument developed in 1987 by Barbara Braden and Nancy Bergstrom, which assists in assessing the risk of developing PI.

The prototype was programmed in a framework available on the free website www.fábricadeaplicativos. com.br. Seven tabs were created: Application Information, Concept and Risks, Staging, Staging Images, Braden Scale, Prevention and References.

The application evaluation was based on the Design Thinking method ${ }^{18}$, which is an approach to problem solving that is based on: empathy, collaboration and experimentation. When a group of people analyze a problem together, it leads to new solutions about that problem. Design Thinking generates problem solving in different ways, creating new options for different aspects, which go beyond improving existing alternatives. The moment the alternatives are generated, experimentation is called, which is called prototyping, which is not only building and verifying if it works, but also an evolutionary process ${ }^{18}$.

After the prototype was ready, it was sent for evaluation by health team participants, in a convenience sample of nine professionals. The convenience sample was used due to the lower cost and time spent in this sampling. The evaluators' participation was performed after agreeing to participate in the study and signing the Informed Consent Form (ICF). The app evaluation process was carried out in two phases. In the first phase, a questionnaire was prepared for health professionals in the sample. The questionnaire had questions prepared by the author, related to the content and form of the application, and the answers could be answered as YES or NO and at the end there was an option to include comments and suggestions. The professionals received the link to access the application and answered the questionnaire sent by email, in which they analyzed the structure, content and accessibility of the language. After these users had made the evaluation, improvements were made until the app had the structure, content and language suitable for the professional's practice. After this phase and the adequacy of the suggestions, phase two of the app's evaluation began. This time, three stomatherapist nurses participated. This category of professionals was chosen because it was the only one that suggested changes in the first phase of the assessment. All three participants submitted the form that agreed with all items. The application was, therefore, considered adequate in the form and content to be made available.

From the prototype evaluated and updated, the end of the application was programmed and made available on the platforms for free download.

\section{RESULTS}

The application developed from the "fábrica de aplicativos" page was called "Sem Pressão” ('No Pressure') (Fig. 1).

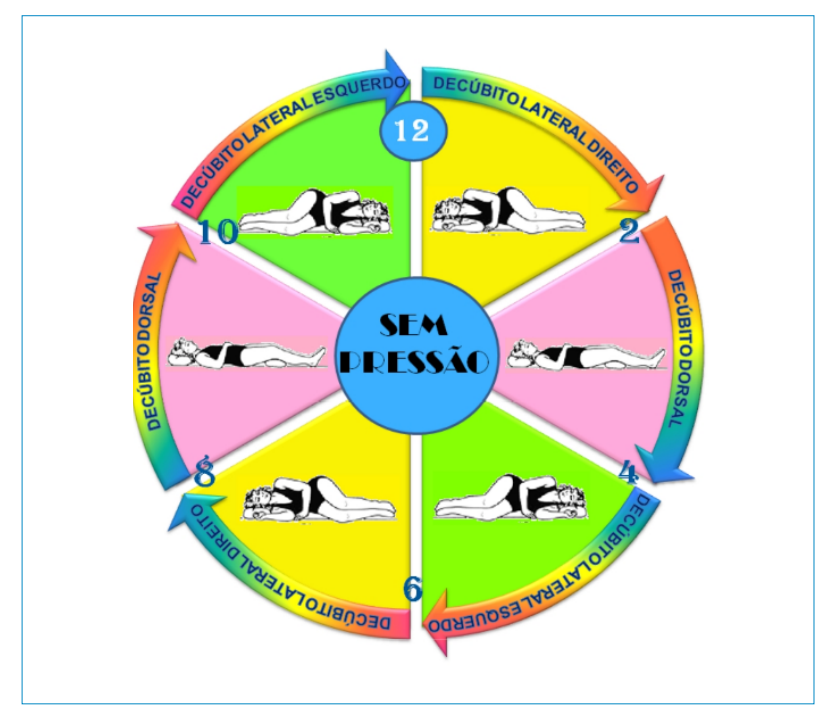

Figure 1. SEM PRESSÃO ('No Pressure') application home screen. São Paulo (SP), Brasil - 2017.

The name of the app came from the main cause of the injury: pressure. Without pressure, the risk of developing this wound is absent. In addition, the occurrence of this type of wound is used as an assessment of the quality of patient care. Thus, health professionals feel pressured to establish preventive programs. The creation of the application name brought these two elements together and was named: "Sem Pressão" ('No Pressure', in Portuguese). 
When opening the application, the home screen presents the developed layout. Then automatically follows the page with the home menu. (Fig. 2).

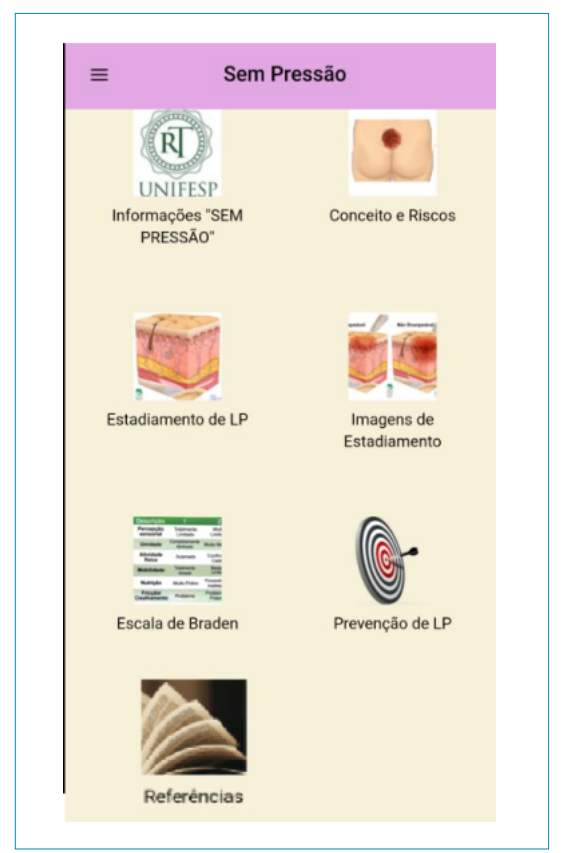

Figure 2. "No Pressure” application home menu screen . São Paulo (SP), Brasil - 2017.

The initial menu (Fig. 2) contains the tabs: Information, Concept and Risks, Staging, Staging Images, Braden Scale, PI Prevention and References. A tab, "Information", was included so that the user knows the origin of the application, the authors and the master's course in which the application was developed. The next tab, "Concept and Risks", was subdivided into three items: Concept, Risk Factors and Risk Regions. The content includes the concept of PI according to the NPIAP, the main risk factors and also the risky body regions.

Fig. 3 shows the "PI Staging" tab. The NPIAP classification has been included ${ }^{1}$ :PI stages 1 to 4 , PI Unclassifiable, PI Deep Tissue, PI by devices and PI in mucous membranes.

The next screen (Fig. 4) shows a sequence of PI images. Each classification has one or more examples in photos to elucidate the concepts. By clicking on a photo, a description of the stage and location of the lesion presented opens.

The Braden scale was included in a specific tab. This tab was expanded into items, in which each subscale was described. When you click on an item it opens with the description. The application then presents the item "Prevention". This item was divided into 11 subitems (Fig. 5): Concept, Inspection and Skin Care, Incontinence, Nutrition and Hydration, Repositioning, Pressure Redistribution, Prophylactic Coverings, PI in the Seated Patient, PI Related to Devices, Prevention in the Surgical Room and Prevention Education.

The last tab was called "References". The main bibliographies used in the development of the application's content were placed.

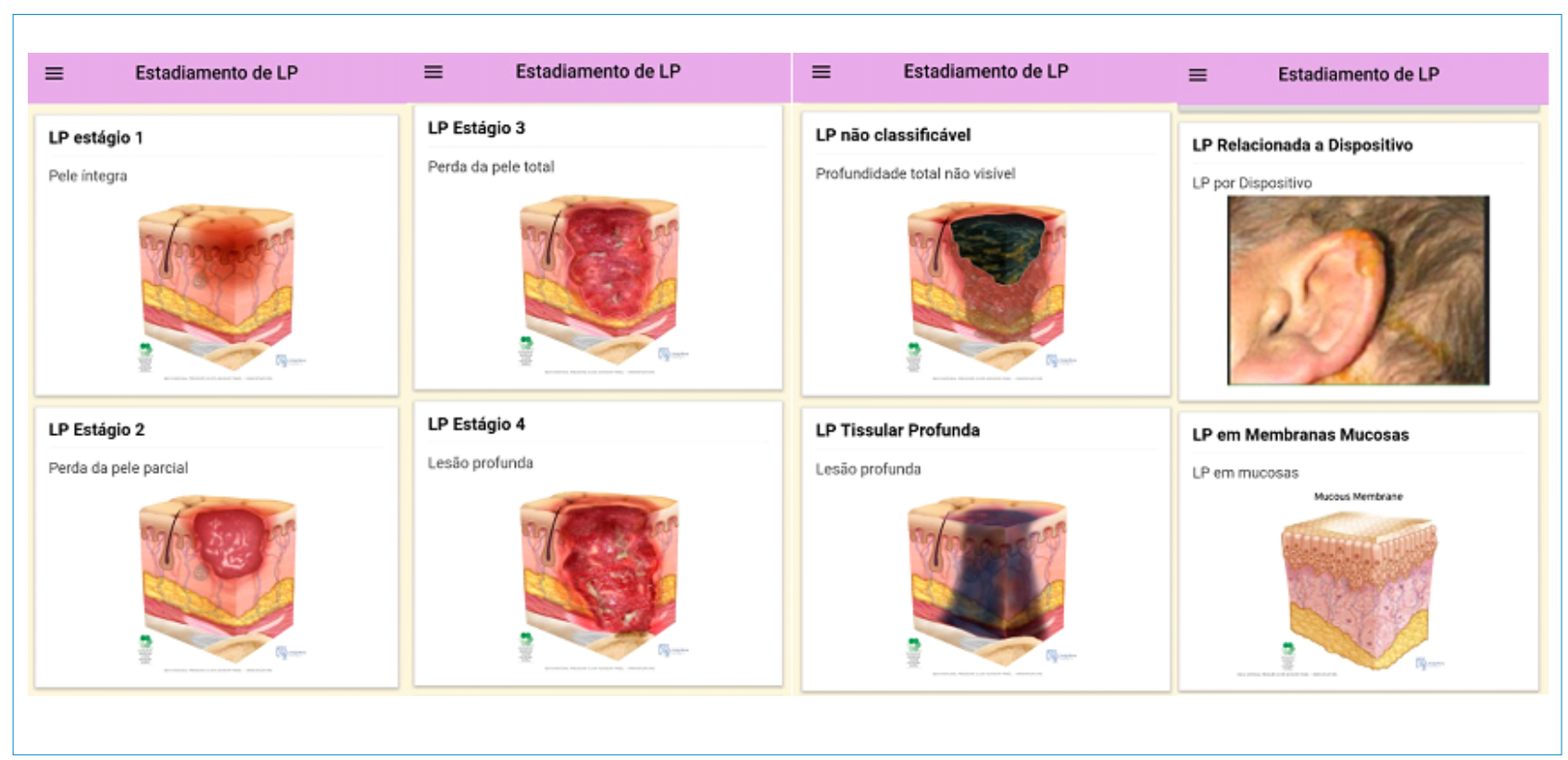

Figure 3. SEM PRESSÃO application pressure injury staging. São Paulo (SP), Brasil - 2017. 


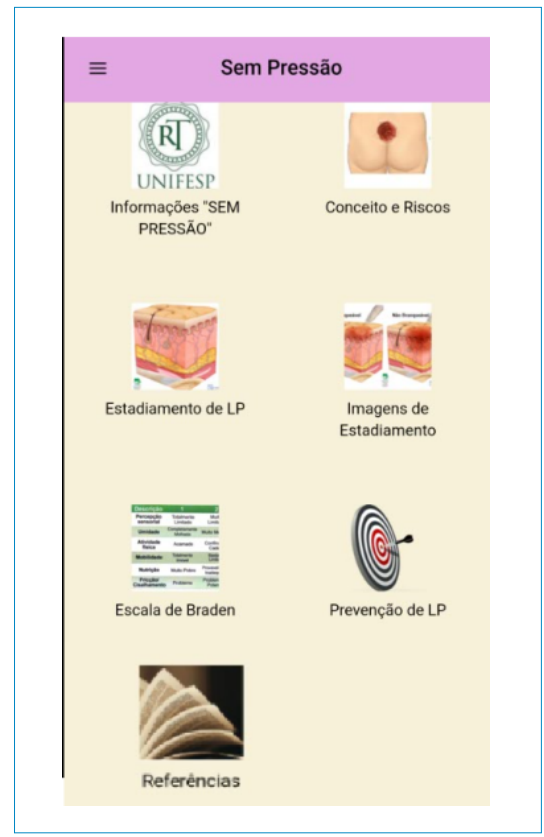

Figure 4. SEM PRESSÃO application pressure injury staging images. São Paulo (SP), Brasil - 2017.

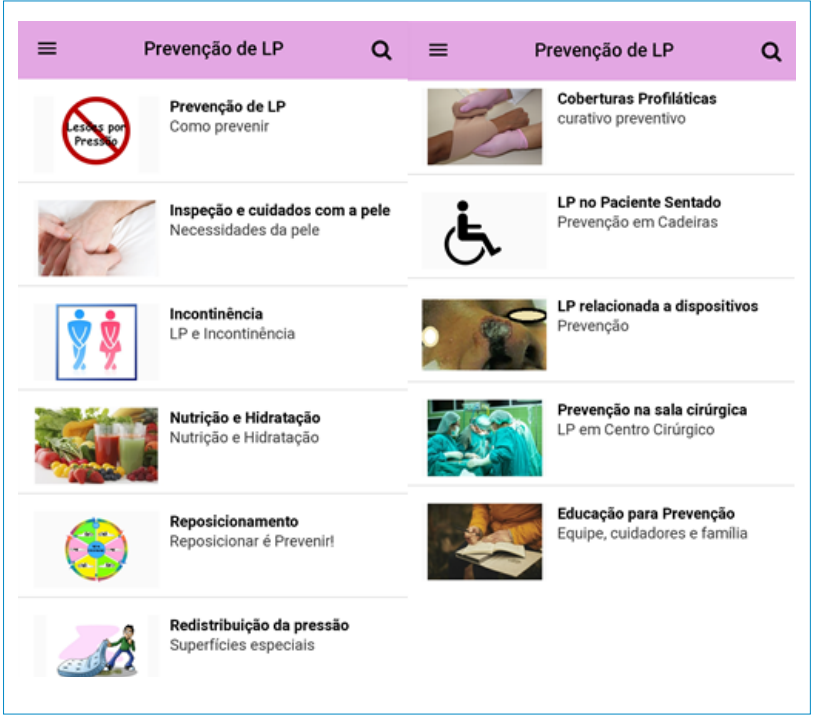

Figure 5. Prevention and sub-items of the application SEM PRESSÃO. São Paulo (SP), Brasil - 2017.

\section{DISCUSSION}

Evidence suggests that PI can be prevented by implementing prevention guidelines that aim to identify known risk factors associated with PI development ${ }^{19,20}$. Therefore, the identification and understanding of risk factors are necessary to provide adequate prevention interventions and make better use of resources in practice ${ }^{10}$.
The theme approach in the "Sem Pressão" application was aimed at health professionals, for identification, staging and prevention in adult patients. The choice of the adult public was due to the large number and variety of publications available on preventing PI. The content sequence of the application was followed as it appears in the known guidelines for preventing PI as of the NPIAP. The concepts presented are the most recent ${ }^{1,17,20}$.

The "Sem Pressão" application design was made available by the creation platform: www.fabricadeaplicativos. com.br. The platform is simple to use, with ready and customizable templates. Soft background colors were chosen, which do not interfere with the educational aspect of the application. The creation platform was chosen for its ease, accessibility and low cost. The positive points of using this method were the speed of development and updating, as well as the practicality of disclosing the link for testing and even for downloading. However, there are limits, such as the rigidity of the platform that does not allow interactions that an educational application needs, for example, to make it possible to insert data and automatically calculate the scores on the Braden scale. The staging illustrations were authorized for use in the app by NPIAP and the rest were found on free image sites like pixabay.com.

Ensuring the effectiveness and safety of applications for use in healthcare is critical given the variability of applications currently available. In addition to demonstrating the accuracy, effectiveness or safety of a given app, rigorous evaluation of these clinical tools can also reveal unexpected results during development ${ }^{21,14}$. The evaluation of the content of "Sem Pressão" was based on the Design Thinking methodology and performed by professionals from the health team, experienced in providing care related to PI. This assessment aimed to give credibility to the app, as well as to ensure that the information contained therein was consistent with international guidelines and clinical practice. The convenience sample used included a physiotherapist who works in early mobilization and prevention of PI in the ICU, a hospital psychologist, three stomatherapy nurses experienced in the PI area and four generalist nurses working in the hospital area with bedridden patients at risk of PI.

In the feedback received from the professionals' evaluations, a relevant point was the inclusion of PI prevention in the surgery room. Tallier and collaborators ${ }^{22}$, in a study on 
PI prevention in this sector, they identified that nurses in the surgery room have a lack of knowledge about the evaluation and prevention of PI, and also that these professionals are not involved in continuing education activities regarding PI. Thus, an application that has a specific prevention item in the surgery room comes to support decision-making about prevention in surgical patients, with quick and timely access, providing increased knowledge and preventive actions.

Timely access to clinical information is a key factor in ensuring an effective and safe care practice. Smartphone application technology has the potential to improve accessibility to data and resources such as clinical and scientific evidence. Therefore, the use of smartphones by health professionals can help improve standards of care ${ }^{23}$ This type of technology gains space in people's daily lives, directly influencing public policies and leading society to add new sociocultural and democratic values, fundamentally exercising the function of educational and informational resources ${ }^{16}$. Applications can be downloaded from anywhere in the world, as long as one has access to the internet ${ }^{24}$ This allows a continental country like Brazil to reach this knowledge tool in the most distant places from large centers. In addition, professionals carry their equipment with them, thus, access to information will happen anywhere, without the dependence of an office or fixed computer.

Providing up-to-date and accurate information is essential to support professionals when they are managing patient care $^{15}$. A mobile app that allows for timely access without spending the internet band, supports the learning and practice of newly graduated professionals ${ }^{25}$. Agu and collaborators ${ }^{24}$ mention that smartphones stay with their users $90 \%$ of the time. This advantage is even greater for home care nurses, as they can have access to information at any time, increasing the efficiency of their diagnostic and preventive actions ${ }^{15}$.
The prevention of the occurrence of PI brings benefits, such as cost reduction, better healing (in case of PI), reduced need for surgical intervention such as debridement or grafting, reduced hospital or home stay, among others ${ }^{15}$. Thus, "Sem Pressão" can assist institutions in reducing costs associated with assistance, in addition to reducing iatrogenic damage from hospitalization.

The individualization of care through the systematization of nursing care and the use of recommendations for evidencebased clinical practices can improve the quality of care and provide benefits to the patient ${ }^{23}$. The creation of an application in Portuguese and free for download is certainly a tool that will disseminate knowledge to professionals, mainly to non-specialists, who, thus, will be able to take initiatives to prevent PI.

\section{CONCLUSION}

An application was developed that is free and in Portuguese, with guidance on identifying, staging and preventing PI in adults, called "Sem Pressão" ('No Pressure') and made available for free download on the Google Play Store ${ }^{\mathrm{TM}}$.

\section{AUTHOR'S CONTRIBUTION}

Conceptualization: Campos RS, Blanes L; Methodology: Campos RS, Blanes L, Ferreira LM; Writing - First version: Campos RS, Blanes L; Writing - Review \& Editing: Campos RS, Blanes L, Nicodemo D, Ferreira LM; Financing Acquisition: Campos RS; Resources: Campos RS; Supervision: Blanes L, Nicodemo D, Ferreira LM.

\section{REFERÊNCIAS}

1. European Pressure Ulcer Advisory Panel, National Pressure Injury Advisory Panel and Pan Pacific Pressure Injury Alliance. Prevention and treatment of pressure ulcers/injuries: clinical practice guideline. The international guideline. Emily Haesler (Ed.). EPUAP/NPIAP/PPPIA: 2019.

2. Caliri MHL, Santos VLCG, Mandelbaum MHS, Costa IG. Classificação das lesões por pressão - Consenso NPUAP 2016 - adaptada culturalmente para o Brasil. Publicação oficial da Associação Brasileira de Estomaterapia (SOBEST) e da Associação Brasileira de Enfermagem em Dermatologia (SOBENDE). 2016. [Acesso em 01 dez 2016]. Available ate: http://sobest.org.br/textod/35

3. Galetto SGS, Nascimento ERP, Hermida PMV, Malfussi LBH. Lesões por Pressão Relacionadas a Dispositivos Médicos: revisão integrativa da literatura. Rev. Bras. Enferm 2019;72(2):528-36. https://doi.org/10.1590/0034-71672018-0530 
4. Black JM, Kalowes P. Medical device-related pressure ulcers. Chronic Wound Care Manag Res 2016;3:91-9. https://doi. org/10.2147/CWCMR.S82370

5. Barbosa JM, Salomé GM. Ocorrência de lesão por pressão em pacientes internados em um hospital-escola. ESTIMA, Braz J Enterostomal Ther 2018;16:e2718. https://doi. org/10.30886/estima.v16.523_PT

6. Constantin AG, Moreira APP, Oliveira JLC, Hofstätter LM, Fernandes LM. Incidência de lesão por pressão em unidade de terapia intensiva para adultos. ESTIMA, Braz J Enterostomal Ther 2018;16:e1118. https://doi. org/10.30886/estima.v16.454_PT

7. Pittman J, Beeson T, Kitterman J, Lancaster S, Shelly A. Medical device-related hospital-acquired pressure ulcers. Development of an evidence-based position statement. J Wound Ostomy Continence Nurs 2015;42(2):151-4. https:// doi.org/10.1097/WON.0000000000000113

8. Mazzo A, Miranda FBG, Meska MHG, Bianchini A, Bernardes RM, Pereira Junior GA. Teaching of pressure injury prevention and treatment using simulation. Esc. Anna Nery 2018;22(1):e20170182. https://doi.org/10.1590/2177-9465ean-2017-0182

9. Galhardo VAC, Magalhães MG, Blanes L, Juliano Y, Ferreira LM. Health-related quality of life and depression in older patients with pressure ulcers. Wounds 2010;22(1):20-6. Available ate: https://www.woundsresearch.com/content/ health-related-quality-life-and-depression-older-patientswith-pressure-ulcers

10. Chacon JMF, Blanes L, Borba LG, Rocha LRM, Ferreira LM. Direct variable cost of the topical treatment of stages III and IV pressure injuries incurred in a public university hospital. J Tissue Viability 2017;26(2):108-12. https://doi.org/10.1016/j. jtv.2016.12.003

11. Dealey C, Posnett J, Walker A. The cost of pressure ulcers in the United Kingdom. J Wound Care 2012;21(6):261-6. https://doi.org/10.12968/jowc.2012.21.6.261

12. Vêscovi SJB, Primo CC, Sant'Anna HC, Bringuete MEO, Rohr RV, Prado TN et al. Mo-bile application for evaluation of feet in people with diabetes mellitus. Acta Paul Enferm 2017;30(6):60713. https://doi.org/10.1590/1982-0194201700087

13. Rouse M. mHealth (mobile health) in: TechTarget [internet]. [Acesso em 30 out 2016]. Available ate: http://searchhealthit. techtarget.com/definition/mHealth

14. Sving E, Fredriksson L, Gunningberg L, Mamhidir A-G. Getting evidence-based pressure ulcer prevention into practice: a process evaluation of a multifaceted intervention in a hospital setting. J Clin Nurs 2017;26(19-20):3200-11. https://doi.org/10.1111/jocn.13668

15. Rodrigues JJPC, Pedro LMCC, Vardasca T, Torre-Díez I, Martins HMG. Mobile health platform for pressure ulcer monitoring with electronic health record integration.
Health Informatics J 2013;19(4):300-11. https://doi. org/10.1177/1460458212474909

16. Pereira FGF; Frota NM; Silva DV; Sousa LMO, Almeida JC; Cysne Filho FMS. Avaliação de aplicativo digital para o ensino de sinais vitais. Rev Min Enferm 2017;21:e1034. https://doi. org/10.5935/1415-2762.20170044

17. Blanes L, Ferreira LM. Prevenção e tratamento de úlcera por pressão. $1^{\text {a }}$ ed. Rio de Janeiro: Atheneu; 2013.

18. Ferreira FK, Song EH, Gomes H, Garcia EB, Ferreira LM. New mindset in scientific method in the health field: design thinking. Clinics (São Paulo) 2015;70(12):770-2. https://doi. org/10.6061/clinics/2015(12)01

19. Coyer F, Tayyib N. Risk factors for pressure injury development in critically ill patients in the intensive care unit: a systematic review protocol. Syst Rev 2017;6:58. https://doi. org/10.1186/s13643-017-0451-5

20. Association of perioperative Registered Nurses [homepage]. Position statement on perioperative pressure ulcer prevention in the care of the surgical patient. AORN Journal 2016;104(5). Available ate: https://aornjournal.onlinelibrary. wiley.com/doi/10.1016/j.aorn.2016.08.011

21. Pokorná A, Jarkovský J, Mužík J, Vasmanská S, Saibertová S, Krejčiř́ḱková P. A new online software tool for pressure ulcer monitoring as an educational instrument for unified nursing assessment in clinical settings. Mefanet Journal 2016; [cited on mar 2020]; 4(1):26-32. Available ate: https:// www.researchgate.net/publication/305810458_A_new_ online_software_tool_for_pressure_ulcer_monitoring_as_an_ educational_instrument_for_unified_nursing_assessment_ in_clinical_settings

22. Tallier PC, Reineke PR, Asadoorian K, Choonoo JG, Campo M, Wallen CM. Perioperative registered nurses knowledge, attitudes, behaviors, and barriers regarding pressure ulcer prevention in perioperative patients. Appl Nurs Res 2017;36:106-10. https://doi.org/10.1016/j.apnr.2017.06.009

23. Mercês JMR, Redeiro MMP. A importância dos dispositivos móveis como estratégia para a formação e desenvolvimento de profissionais de saúde. UERJ 2016; [cited on feb 2020]; Available ate: http://www.abed.org.br/congresso2016/ trabalhos/306.pdf

24. Agu E, Pedersen P, Strong D, Tulu B, He Q, Wang L et al. The smartphone as a medical device: assessing enablers, benefits and challenges. IEEE International Workshop of Internet-of-Things Networking and Control (IOT-NC) 2013:76-80. https://doi.org/10.1109//oT-NC.2013.6694053

25. Bullock A, Dimond R, Webb K, Lovatt J, Hardyman W, Stacey M. How a mobile app supports the learning and practice of newly qualified doctors in the UK: an intervention study. BMC Med Educ 2015;15:71. https://doi.org/10.1186/s12909-0150356-8 